\title{
COMENTARIO SOBRE LA POESÍA ACTUAL EN PUERTO RICO
}

\author{
POR \\ DANIEL TORRES \\ Ohio University
}

Desde los años sesenta y setenta, las nuevas generaciones de poesía puertorriqueña se han formado alrededor de un círculo que colabora en una revista literaria. Éste ha sido el caso de Guajana (1962), Mester (1967-70), Ventana (1972) y Zona de carga y descarga (1972-1975).

Los poetas "nuevos" del ochenta se agrupan, a su vez, alrededor de varios cenáculos literarios alternativos como lo fueron las diferentes revistas universitarias: Filo de juego (1984-87), Tríptico (1987-1989) y Extremos líricos del Caribe a la Araucania (19861989).

Taller de poesía 1981 fue una de las publicaciones iniciales de muchos de los miembros de esta generación (o promoción). Esta antología fue publicada como producto del taller que dictara la poeta María Arrillaga en la Facultad de Estudios Generales del Recinto de Río Piedras de la Universidad de Puerto Rico.

Otras dos antologías de este grupo fueron realizadas por el profesor Manuel de la Puebla: Poesía joven en Puerto Rico (1981) y, en colaboración con Marcos Reyes Dávila, Poesia universitaria 1982-83.

Como puede verse por medio de esta lista de revistas y de antologías, el grupo de poetas puertorriqueños de los ochenta no es necesariamente un grupo totalmente inédito. Mucho se ha discutido acerca de su visibilidad en el quehacer literario en Puerto Rico, pero en apenas diez años se ha desarrollado como una promoción con una presencia propia. Dos editoriales nuevas como Tríptico (del grupo de la revista del mismo nombre) e Isla Negra han dado a conocer varias de las obras de estos escritores. La colaboración con los poetas de los setenta ha sido también fructífera, piénsese en el caso del poeta Che Meléndez, quien les ha dado la oportunidad a poetas como Rafael Acevedo de publicar su Libro de islas en la editorial Qease.

El corpus de libros de poesía publicados por los poetas de los ochenta es como sigue: de Rafael Acevedo, poeta eje del grupo por su madurez lírica notable, Contracanto a los superdecidores (1982), El retorno del ojo pródigo (1986), Libro de islas (1989); de Luis Raúl Arbadalejo, el lírico par excellence de esta promoción, El revés de la caricia (1991); de Carlos Gómez-Beras, el libro ganador del Premio Nacional del PEN Club de Puerto Rico 1990-1991, Viaje a la noche (1990); de Zoé Jiménez-Corretjer, la poeta metafísica, Crónicas interplanetarias (1990), Las menos cuarto (1985), Poemanaciones (1991); del 
vanguardista empedernido Edgardo Nieves-Mieles, una de las voces de mayor resonancia junto a Acevedo y a Mayra Santos-Febres, El ramalazo de semen en la mejilla ortodoxa: de cómo un poeta recién casado corteja la poesía a escondidas de su esposa y otras taquicardias (1987); del enigmático Obed-Edom, Sacrificio al sacerdote del abismo (1978), de Mayra Santos-Febres, la poeta feminista, Anamú y manigua (1991) y El orden escapado (1991), Premio del Concurso de la revista Tríptico (1991).

Emitir un juicio de valor sobre poetas incipientes es siempre una de las tareas más ingratas para cualquier crítico, pero sí se pueden apuntar las tendencias o reconocer los diálogos o silencios que se establecen con la tradición que antecede a toda obra literaria. En este caso, varios críticos se han pronunciado al respecto. Mario R. Cancel etiqueta la generación del ochenta desde la perspectiva política:

Nosotros somos los hijos del "Estado Libre Asociado", pero también somos los hijos de la generación revolucionaria por excelencia: el ' 60 . En nuestra evolución, aquellos que en el 1980 atacamos al '60, nos hallamos ahora trabajando a su lado. Igual sucedió con las relaciones del ' 60 con la gente del ' 30 y el ' 50 . Es cuestión de conciencia histórica. (20)

Otro crítico, el profesor Adolfo E. Jiménez Benítez agrega a esta ficha política de la promoción:

Estos poetas (que nacen bajo la vigencia de la ley 600), intentan trazar con originalidad nuevos senderos en la actual lírica puertorriqueña de finales del siglo XX. En la eterna búsqueda de explicaciones, otra vez nos encontramos ante la encrucijada históricoartística, con la conciencia de que debemos valorar y descubrir siempre lo que está en el fondo: el ser puertorriqueño. (22)

Tanto las referencias al ELA y a la Ley 600 son aquí evidencia de que no se puede hablar de la evolución histórica literaria de Puerto Rico sin hacer mención al problema colonial de la isla.

Por otro lado, el profesor Jiménez Benítez expresa las características primordiales de esta poesía, cuando dice:

Este grupo de poetas, donde el quehacer femenino se deja sentir significativamente, superan de manera distinta el compromiso social y politico de Guajana o Mester, por ejemplo, haciendo uso de un lenguaje, en cierto modo anarquizante, nuevo y diferente, punzante y coloquial; cuyo objetivo es, al parecer, transformar la realidad cotidiana en arte. (22)

Acercándonos un poco más a las figuras del grupo, en Rafael Acevedo encontramos no sólo el poeta de mayor producción poética hasta este momento, sino también una de las voces que ya llamé "eje". El poeta setentista José Luis Vega, en su reseña del Libro de islas, se refiere a la obra de Acevedo de la siguiente manera:

Lo mejor del lenguaje poético de Rafael Acevedo se mueve entre dos extremos. De un lado nos topamos con un estilo fluido y surrealizante, que emplea, sobre todo, en el discurso 
amoroso de la segunda parte del libro: "Lo triste es que he perdido el pasaporte para ir de mi cuarto menguante a la sonrisa que sale por la puerta, tampoco queda tiempo pues he perdido el reló así que no hay prisa, estoy buscando lo que no se me ha perdido, tu número de teléfono para decirte cosas como quieres ir al cine" (58). En el extremo opuesto, el estilo poético de Acevedo tiende a la concisión conceptista que emplea, preferentemente, en algunos poemas de la tercera parte, como el titulado Errata de fe: "El marx/es/azul". (96) (14)

Otras dos figuras que me interesa destacar aquí son Mayra Santos-Febres y Edgardo Nieves-Mieles. Carmen Dolores Trelles se refiere al lenguaje poético de Santos-Febres como:

... fresco y refrescante: nuevo en sus combinaciones. No es sólo que recurra a un marco de referencia cotidiano y centrado en una experiencia muy étnicamente localizada de la vida diaria y de las costumbres domésticas y familiares. Se trata también de las metáforas inesperadas, sorprendentes, de la precisión y graficidad de las imágenes y, sobre todo, de las resonancias ocultas - de proyecciones universales - que surgen tras estos poemas. (18)

Puede añadirse que Santos-Febres es la poeta mujer y negra que hace poesía de su tradición. En su poema, "Abuela" puede apreciarse esta preocupación:

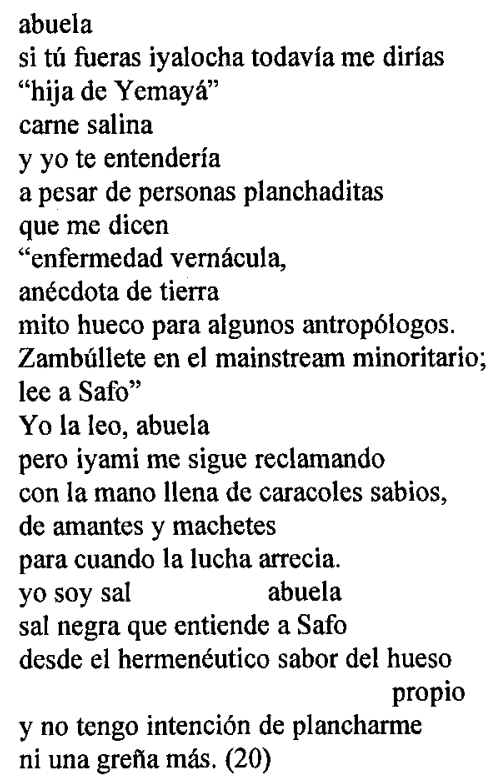

Si por un lado Santos-Febres intenta rescatar la tradición femenina, por el otro Edgardo Nieves-Mieles se regodea en el canon literario y cultural. En su discurso poético se conjuga 
el placer de la lectura y del análisis junto a la obsesión por la escritura: "Este escrito es un sacrificio/más sobre el altar del análisis" (33). Hay en su palabra la actitud desacralizante del que se sabe creador, como ejemplifica su poema "De oficio, poeta":

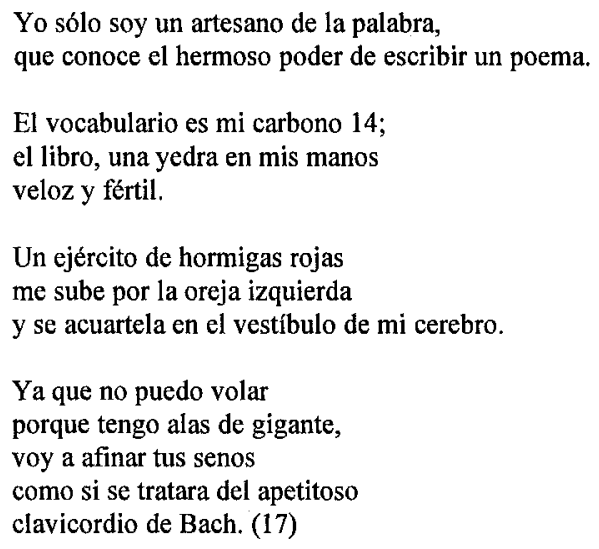

Con esta brevísima muestra he intentado comentar acerca de la poesía actual en Puerto Rico. Es sumamente difícil en este momento hacer un análisis de conjunto. Lo que convendría sería un estudio de cada uno de los libros de poesía en sus diferentes especificidades literarias para poder apreciar el proyecto común de la generación del ochenta en la literatura puertorriqueña contemporánea.

\section{Obras Citadas}

Cancel, Mario R. "Mayagüez y la llamada Generación del '80". En rojo (12-18 de enero de 1989), 20-21.

Jiménez Benítez, Adolfo. "Consideraciones sobre un punto de vista generacional: La poesía puertorriqueña de los ochenta". En rojo (12-18 de enero de 1989): 22.

Nieves-Mieles, Edgardo. El ramalazo de semen en la mejilla ortodoxa. Arecibo: Ricardo Garúa, 1987.

Santos-Febres, Mayra. Anamú y manigua. Río Piedras: La iguana dorada, 1991. Trelles, Carmen Dolores. "Las raíces del recuerdo". El nuevo día (14 de julio de 1991), 18. Vega, José Luis. "Poemas para las Antillas". El nuevo día (24 de diciembre de 1989), 14. 